\title{
Cultural concepts of parenting. A linguistic analysis*
}

\author{
Elke Hentschel (Bern)/Heidi Keller (Osnabrück)
}

\begin{abstract}
This study is part of a larger cross cultural research project on "parenting ethnotheories", where mothers of three months old infants were interviewed about their ideas on good parental care for small babies. They were confronted with picture cards, displaying different parenting behaviours from their own cultural community and were asked to comment on the appropriateness and inappropriateness of such behaviour. This paper addresses 40 of the German language interviews with a total 78,484 words. The central focus of this analysis is the frequency and distribution of modal particles as used in these interviews and as compared to two other corpora with a total of 60,000 words. The results indicate substantial differences with respect to the most frequently used particles, which can be explained by the attitudes of these women towards the particular topic being addressed in the interviews. The particle halt was used 17 times more often, whereas the usually very frequent doch was used 16 times less than usual. Based on the meaning of these particles in the German language, conclusions can be drawn concerning the more or less conscious representation of parenting ideas. The women interviewed regarded their ideas as unchangeable (as expressed in halt) and are convinced that others share their worldview (as expressed in the low incidence of doch).
\end{abstract}

\section{$1 \quad$ Introduction}

It is widely acknowledged that psychological phenomena are constituted by cultural processes that operate on biological predispositions. Cultural processes are evident in shared activities and shared ideas. In this sense cultural concepts are collective products that emerge from social processes and transcend any individual idea (Ratner 2002). Parental attitudes towards socialization and child development constitute such cultural concepts that are shared among members of sociocultural communities (Keller/Yovsi/Voelker 2002; Keller/Voelker/Yovsi 2005; Keller et al. 2004; Super/Harkness 1996; LeVine 1988).

A characteristic of cultural concepts of parental ideas and belief systems on socialization and child development is that their nature is implicit (D'Andrade, 1984; Weisner/Gallimore/Jordan 1988). Therefore, specific contents such as developmental timetables and customs of childcare may be adopted readily by a person from their culture and these become their personal beliefs, with little, if any, reflection, questioning or consideration of alternatives (Goodnow 1985). Culturally determined parental ideas and belief systems have generally been analyzed with respect to differences in content. For example it has been repeatedly demonstrated that Euro American middle class parents value autonomy and independence in their children, whereas Asian, African, South and Middle American parents value relatedness, obedience and proper demeanor (Harwood 1992; Keller/Demuth/Yovsi 2004).

\footnotetext{
* We would like to thank our two anonymous reviewers for their helpful suggestions. We could not follow all of the suggestions made by one of the reviewers as this would have resulted in a qualitative analysis, and we wish in this paper to focus primarily on a more qualitative analysis. We will, however, bear them in mind for the next paper.
} 
However, cultural concepts are also objectified in linguistic terms (e.g. Shweder 1995; D'Andrade 1984). For this reason Keller, Hentschel et al. (2004) have embarked on a study of the linguistic means employed in narratives of cultural concepts of socialization and child development. To this end these authors analyzed interviews conducted with mothers of three month old infants in three different cultural environments (for more details, see below). The results show that cultural communities differ with respect to the embodied conception of the self as expressed on several levels of linguistic encoding.

In this present study we would like to address a different aspect of the linguistic embodiment of cultural concepts: the degree of unanimity in cultural concepts of parenting as they are shared by a particular socio-cultural community, in this case: middle class families in Berlin. German urban middle class families have been described as following an individualistic or independent script of child development from birth. Western middle class parents address the infant as a quasi-equal partner in interactions and acknowledge the mental model of the child focusing on his or her personal attributes, preferences and judgments (Keller 2003; Keller et al. 2004; Keller/Demuth/Yovsi 2004; Wang 2001; Miller et al. 1997). The discourses are dyadically organized and center on the physical environment (Rabain-Jamin/Sabeau-Jouannet 1997). Parents speak to the infant as if the infant has the capacity to act in a goal directed and intentional fashion (Ochs 1982). This interactional mode is based on individual responsibility and free choices of actions and opinions (Keller 2003), implying substantial interindividual variability. Therefore, it can be assumed that concepts of parenting relate to the independent cultural model represent loose frameworks with substantial space for individual and idiosyncratic constructions. On the other hand, it has been argued, that customs of childcare may be adopted readily from a specific culture and directly become the personal beliefs which cause individuals to question or consider alternatives (see above). This would imply unanimity in cultural concepts of parenting in particular socio-cultural environments.

The present paper is aimed at analyzing the degree of unanimity in cultural concepts of parenting among German middle class mothers with three month old infants, as it is reflected in their language use.

\section{Modal particles}

Whereas some types of linguistic data, such as autosemantic elements, can be, and often are, selected and employed quite consciously by the speaker, others are less open to conscious influences. Thus, discourse marking elements are, by their very nature, generally chosen less consciously. As Kasper (1997) remarks: "Even the most proficient conversationalist has little conscious awareness about turn-taking procedures and politeness marking" - although, one might add, even the least proficient conversationalist is very likely to become aware of a breach of the turn-taking protocol, for instance when being interrupted by somebody else. Among the wide range of different discourse marking elements, the so-called modal particles are supposedly the least conscious. They can neither be accentuated nor occur at the beginning of a sentence, and since they fulfill no syntactic function either, they tend to be overlooked by speakers and hearers, at least consciously. Their communicative function in discourse is, however, a very important one. This type of particle does not exist in all languages, but German is one language that shows them in abundance. ${ }^{1}$

In German, the modal particles - also called "Abtönungspartikeln" ('gradating particles') form a group of particles such as ja, denn, eben in particular functions, e.g. Du weißt ja, wie

\footnotetext{
${ }^{1} \mathrm{Cf}$. Weydt/Ehlers (1987) for an earlier survey of contrastive work that had been done on modal particles until the late 80th, as well as Blühdorn and Schmidt-Radefeldt (2003) or Monteiro Resende (1995) for some examples of more recent language comparisons.
} 
das ist ('You know how it is'); Wie spät ist es denn? ('What time is it?'); Das ist eben so ('That's how it is'). As has been mentioned above, they are all incapable of carrying the accent, they cannot occur in sentence-initial position or used as an answer to a question, and no syntactic function is assigned to them. It is interesting to see that they all have homonyms in other word categories that can be accentuated, used in sentence-initial position etc. Our examples have the following homonyms: $j a$ is an answering particle ('yes'), denn is a conjunction ('for') and the adjective eben means 'flat' or 'equal'. The modal particles are historically related to their homonyms (see e.g. Hentschel/Weydt 2002).

The general function of all modal particles is to situate the discourse in a specific context. Furthermore, each individual modal particle has an individual function: $j a$ implies that the content of the discourse is known to the speaker as well as to the listener; denn is exclusively used in interrogative sentences and refers to a situational component of the question; eben characterizes the proposition of the surrounding sentence as absolute and unchangeable from the point of view of the speaker (cf. ibid.).

There is no consensus in the literature about the number of modal particles in the German language. However, the following list is undisputed: aber, bloß, denn, doch, eben, eigentlich, einfach, etwa, ja, halt, mal, nur, ruhig, schon, vielleicht, wohl and nun mal as a combination term. The frequency of usage of these modal particles varies substantially. E.g. modal particles like aber and vielleicht, which express surprise and astonishment (cf. Das ist aber ein langer Brief! appr. 'What a long letter this is!; Das Bild sieht vielleicht komisch aus! appr. 'How strange the picture looks!'), only occur when these emotions are addressed. How often they occur depends upon a large range of circumstances, but one would certainly not expect them to be felt, and thereafter expressed, in every conversation. Moreover, there are also other linguistic and paralinguistic means used to express surprise and astonishment. Accordingly, only three graduating uses of aber and none of vielleicht could be identified in the only existing statistical study of modal particle use (Hentschel 1986: 245), an analysis of 23 discourse transcripts. ${ }^{2}$

The relative frequency hierarchy of modal particles in the German language was also computed on the basis of this study (see table 1; cf. ibd.: 247).

\footnotetext{
2 Ortmann (1975), using the so-called Kaeding corpus, assigned the frequency rank of 32 to aber and that of 206 to vielleicht. Ruoff (1981) found 3.84\% aber and $0.7 \%$ vielleicht in a corpus of spoken language. However, in each case only occurrences of the words as such were counted. There is no way to tell how many of them were used as graduating particles.
} 


\begin{tabular}{|c|c|c|}
\hline Rank & Particle & $\begin{array}{c}\text { Percentage in comparison to all } \\
\text { particles used }\end{array}$ \\
\hline 1 & $j a$ & $26,3 \%$ \\
\hline 2 & doch & $18,0 \%$ \\
\hline 3 & mal & $16,1 \%$ \\
\hline 4 & auch & $9,0 \%$ \\
\hline 5 & eben & $8,8 \%$ \\
\hline 6 & denn & $4,9 \%$ \\
\hline 7 & schon & $3,2 \%$ \\
\hline 8 & eigentlich & $2,8 \%$ \\
\hline 9 & einfach & $2,6 \%$ \\
\hline 10 & wohl & $2,4 \%$ \\
\hline 11 & halt & $1,9 \%$ \\
\hline 12 & aber & $0,6 \%$ \\
\hline 13 & bloß, etwa, nur, nun mal, ruhig & $0,2 \%$ each \\
\hline
\end{tabular}

Table 1: Ranking of modal particles according to Hentschel (1986)

Apart from the relative frequency of German modal particles, this and related analyses (cf. ibd.: 238-246; Hentschel 1980) provided evidence of a statistically highly significant correlation between the absolute particle frequency and a set of contextual and situative features of a conversation. Particle occurrence and frequency can therefore also be interpreted as a strong indicator for conversational features and attitudes.

In the present study we will mainly employ quantitative methods. ${ }^{3}$ Initially, all modal particles in the underlying corpus, which comprised circa 20,300 words, were analyzed "by hand". This was necessary simply because all relevant words have homonyms in other functions. ${ }^{4}$ Hence, a mechanical counting of words would inevitably lead to completely different results as it would not distinguish between e. g. the various functions of wohl in Ich fühle mich wohl ('I feel good') and Er fühlt sich wohl nicht so gut ('It seems he doesn't feel too well'). In such cases, the distinction is rather simple. However, this is not always the case. For example, in practice the range between a gradating auch that offers the propositional content of the utterance in an imagined, not explicitly mentioned and often not even subsequently namable general context, and the additive focus particle auch which marks the theme of the sentence as something that also applies to another somehow similar fact, can be so unclear that an exact classification might not be $100 \%$ possible even after having listened to the original recording several times. The potential rate of error related to the final classification depends on the time spent evaluating each occurrence of the relevant word. A corpus with a little more than 20,000 words already requires a major expenditure of time in order to analyze

\footnotetext{
3 For qualitative analyses of the same material, see for instance Keller/Hentschel et al. (2004) and Keller/Demuth (2005).

${ }^{4}$ It is therefore not surprising that the relative ranking of the same linguistic elements that can be obtained by comparing their absolute frequences in Ortmann (1975) is quite different: 1. auch, 2. aber, 3. nur, 4. doch, 5. denn, 6. schon, 7. ja, 8. wohl, 9. eben, 10. vielleicht, 11. etwa, 12. bloß, 13. mal, 14. eigentlich, 15. ruhig, 16. einfach, 17. halt.
} 
and categorize each occurrence of the word auch carefully. A corpus of almost 90,000 words, as is the case in the following example, requires such an immense expenditure of time that a careful analysis of each single occurrence becomes almost impossible. The corpus comprises a total of 1,887 occurrences of the word auch.

\section{The Berlin Corpus}

In the following, we refer to a corpus comprising 41 interviews with mothers of 3 month old infants living in Berlin, Germany. The interviews were conducted as part of the project Parental Ethnotheories, which aims at analyzing ideas of parenting and parenting practices across different cultural environments. The Berlin samples comprise highly educated middle class families recruited through a local birth clinic. The mothers were, on average, 33,8 years of age and had 15 years of school attendance. $40 \%$ of the mothers were married. About $70 \%$ of the children were firstborns, and $47 \%$ were girls. The mothers were interviewed individually in their homes. Each mother was shown five picture cards depicting mothers from her own cultural background interacting with infants of three months. The pictures were chosen to represent the five parenting systems "primary care" (breast feeding), "body contact", "body stimulation", "object stimulation" and "face-to-face interaction", as specified in the component model of parenting (Keller 2002; Keller, Lohaus et al. 2004). The mothers were asked to comment on the pictures, ranking them in terms of the importance of such behaviour for an infant of three months. In the next phase, three cards were presented, demonstrating three qualities of each parenting system, e.g. close, loose and no body contact specifying the body contact system. Again the mothers were questioned on their opinions as to the best form of maternal care. The average duration of an interview was 30 minutes.

The interview sessions were audio recorded and transcribed fully afterwards. The transcriptions were completed by transcribers without linguistic training and, therefore, contain only the pure wording of the interview as perceived by the transcriber. However, all recordings were controlled by a second researcher, whose task was to check that these transcriptions corresponded to the exact wording of the interviewees, and to ensure that all discourse and hesitation markers (like $u \mathrm{hm}$ etc.) were included. It can therefore be safely assumed that the transcripts are reliable in this sense. During the following linguistic analysis of the transcripts it became clear that one of the interviews - the interview with the sequential number 4 - was conducted with a mother who is not a native German speaker. This interview has been omitted in the following analysis as it is not possible to discern whether the linguistic particularities of the utterances actually go back to the intentions of the speaker or whether they reflect interferences from another language, or language inadequacies in the second language. The total number of interviews included in the study thus amount to 40 . These 40 interviews still comprised 88,224 words of which 78,484 were uttered by the interviewees and 9,740 by the interviewers. 5 The following analysis only includes the utterances of the mothers.

\section{$4 \quad$ Analysis}

When assessing the particle frequency and particle hierarchy in this corpus, and especially when comparing this data with previous data, we were confronted with the problem that - due to the vast amount of material - not all particles could be analyzed with regard to allocating them to the class of modal particles. As already mentioned above, this was particularly the case with the particle auch. In this case, however, it is more acceptable to do without an allocation than in other cases to the extent that the homonym also belongs to the class of

\footnotetext{
5 The number 9'740 includes feedback signals like for example $M \mathrm{hm}-\mathrm{mhm}$ that were each also counted as one word. The number of feedback signals of the interviewers amounted to a total of 844 .
} 
particles, because it is an additive focus particle. While the function of the modal particles within an assertion sentence ${ }^{6}$ consists of embedding the entire sentence in a coherent way in the broadest sense of the context, including the implicit general world knowledge (univers $d u$ discours), the focus particle establishes a closer relationship between the theme of the sentence and a further fact of the same type. Here is an example for better illustration: in the sentence (...) aber wir haben ja auch einen [i. e. einen Wipper] ('but we have also got one [i. e. a baby bouncer]'; interview 41) the speaker, by using auch, obviously refers to the baby bouncer that she sees on the picture shown to her; auch expresses that owning the described object applies both to the mother on the picture and to the speaker. By contrast, an utterance such as dass ich auch alles richtig mache (appr. 'that I'm doing everything the way it should be done'; interview 5) does not refer to something that was said before or to other immediately visible alternative possibilities. Here, auch puts the sentence in context with everything that could possibly be taken into consideration, as well.

The two uses of auch are clearly examples of two different functions; there is not always a clear-cut distinction between the different usages of the particles. At the same time, however, it becomes clear that both functions establish a relationship to the context that basically only differs in the degree of explicity. To this extent, it is reasonable to assess all occurrences of auch in the same way: each time a mother uses auch in an interview, she relates her comment or parts of it to other phenomena and thus locates them.

While the assessment of the particle auch was extended to all occurrences, it was reduced to 0 in the case of two other particles: wohl and mal. Both particles belong to the same type of word, however, they differ significantly from all other assessed particles in their meaning and pragmatic function. Wohl ('probably') semantically stands in a row with modal words such as vielleicht ('maybe'), sicherlich ('surely'), or möglicherweise ('possibly'), and marks the proposition as only applying potentially, as assumption. Of course this kind of evaluation of an utterance by the speaker is also relevant; however, it needs to be assessed and analyzed in relation to other elements influencing the truth conditions, such as modal verbs, the already mentioned modal words and the use of mode. The particle wohl, which will not be further considered here, was found in eleven of the 40 interviews: twice in one interview, ${ }^{7}$ and once in each of the other ten.

The second particle, that was not included in the further analysis, is mal. It has the effect of adding a perfective aspect to the predicate which might hint to something in the future (jetzt leg ich das Kind mal ab, appr.: 'I'm going to put the child down for a moment'; Interview 6) or which might typically soften a request (cf. Hentschel 1991 and 2001). In the latter case, we obviously cannot expect to find any proof in the interviews, as the mothers did not address any requests to the interviewer. The total occurrence of $\mathrm{mal}$, including the non-modal variants amounting to 524, was rather high. What is of particular interest in the context of the present study is the frequent use of formulas of the type ich denk mal (appr. 'well, I think') and sag ich jetzt mal (appr. 'let me put it this way'). Here we have a case of explicit self reference by naming the judging person, being softened by the addition of mal. The use of the particle thus is to be regarded as parallel to other formulas with similar semantics (cf. würd' ich meinen, appr. 'I'd think so', and the like) and would need to be analyzed together with them. Particle

\footnotetext{
6 Except for assertion sentences, auch may also occur in a modal function in interrogative sentences of both types, i.e. in Yes-No-questions and in open questions. In Yes-No-questions, it conveys a clear reassurance character of the question (cf. Haben wir auch alles? 'Have we got everything?'; Hast du auch an alles gedacht? 'Have you thought of everything?') while in open questions it serves to mark the question as rhetorical (Was hätte ich auch tun können? 'What could I have done, after all?'):

${ }^{7}$ In both cases with reference to the same fact: das ist wohl der Schreireflex der natürlich angeboren ist 'This is probably the screaming reflex that is naturally innate; das ist wohl auch son, son Reflex 'that is probably also such a such a reflex' (interview 15):
} 
use in this kind of utterance is very important and must, of course, be taken into account when analyzing self references in these interviews. This was not the object of the present study, so from this point of view, mal could be excluded without any difficulties.

However, we still had to make sure that nothing significant was lost by this procedure. On the one hand, the increased number of particles could only be compared to a limited extent with those of the study of 1986. On the other hand, it was necessary, before definitely excluding mal and wohl, to find out whether any significance might be hidden behind their usage that would get lost by their exclusion from further analysis. Therefore, an additional corpus was created especially for comparison purposes, containing 12 interviews - in other words, all of them belonging to the same text sort as the Berlin corpus and therefore especially qualified for comparative purposes - from the corpus collected by the Institute for German Language (Institut für deutsche Sprache) in Mannheim. ${ }^{8}$ From this corpus, which comprises 38,477 words and will be referred to subsequently as "comparative corpus", we now extracted the complete data following the procedure used for the Berlin corpus. The relative results for mal turned out to be $11,1 \%$ of all assessed particles in one case (Berlin corpus), and 9,8\% (comparative corpus) in the other case, thus differing by the factor 0,1 . The results for wohl showed a significantly bigger deviation with $0,3 \%$ (Berlin corpus) and 1,6\% (comparative corpus) of all words; however, in light of the small total numbers (12 resp. 15 occurrences of the particle) as well as in light of the fact that despite the relatively higher frequency of wohl, in exactly half of the interviews of the comparative corpus, there was no occurrence of wohl at all, no further conclusions can be drawn from this difference.

This led to the following results:

Berlin corpus without mal and wohl:

Comparative corpus without mal and wohl:

\begin{tabular}{|c|c|c|}
\hline Particle & absolute & $\%$ \\
\hline auch & 1887 & $45.0 \%$ \\
\hline halt & 611 & $14.6 \%$ \\
\hline ja & 515 & $12.3 \%$ \\
\hline einfach & 401 & $9.6 \%$ \\
\hline eben & 333 & $7.9 \%$ \\
\hline eigentlich & 199 & $4.7 \%$ \\
\hline schon & 182 & $4.3 \%$ \\
\hline doch & 47 & $1.1 \%$ \\
\hline denn & 15 & $0.4 \%$ \\
\hline nun mal & 3 & $0.1 \%$ \\
\hline ruhig & 1 & $0.0 \%$ \\
\hline Total & 4194 & $100.00 \%$ \\
\hline
\end{tabular}

\begin{tabular}{|c|c|c|}
\hline Particle & absolute & $\%$ \\
\hline auch & 340 & $40.1 \%$ \\
\hline ja & 177 & $20.9 \%$ \\
\hline doch & 152 & $17.9 \%$ \\
\hline eigentlich & 61 & $7.2 \%$ \\
\hline eben & 38 & $4.5 \%$ \\
\hline einfach & 28 & $3.3 \%$ \\
\hline denn & 22 & $2.6 \%$ \\
\hline schon & 16 & $1.9 \%$ \\
\hline halt & 7 & $0.8 \%$ \\
\hline nun mal & 4 & $0.5 \%$ \\
\hline ruhig & 2 & $0.2 \%$ \\
\hline Total & 847 & $100.00 \%$ \\
\hline
\end{tabular}

Table 2: Particle ranking, Berlin corpus

Table 3: Particle ranking, comparative corpus

\footnotetext{
8 We refer to the transcriptions marked by the abbreviations DS031, DS069, FR015, FR023, FR102, FR150, FR152, FR163, FR164, FR172, FR219 and IS010 of the Mannheim corpus.
} 
Relation Berlin corpus/comparative corpus and vice versa, without mal and wohl, respective factors:

\begin{tabular}{|c|c|c|}
\hline Particle & $\mathrm{B} \Rightarrow \mathrm{C}$ & $\mathrm{B} \Leftarrow \mathrm{C}$ \\
\hline auch & 1.1 & 0.9 \\
\hline denn & 0.1 & $\mathbf{7 . 3}$ \\
\hline doch & 0.1 & $\mathbf{1 6 . 0}$ \\
\hline eben & 1.8 & 0.6 \\
\hline eigentlich & 0.7 & 1.5 \\
\hline einfach & 2.9 & 0.3 \\
\hline halt & $\mathbf{1 7 . 5}$ & 0.1 \\
\hline ja & 0.6 & 1.7 \\
\hline ruhig & 0.1 & $\mathbf{9 . 9}$ \\
\hline schon & 2.3 & 0.4 \\
\hline nun mal & 0.2 & $\mathbf{6 . 6}$ \\
\hline
\end{tabular}

Table 4: Frequency comparison between Berlin and comparative corpus

( $\mathrm{B}=$ Berlin corpus, $\mathrm{C}=$ comparative corpus; the arrow shows the direction of the relation)

Significant differences could be shown particularly for the particles doch (comparative corpus: 16 times higher frequency) and halt (Berlin corpus: more than 17 times higher frequency). The particle denn also showed a relatively big difference in frequency (comparative corpus: 7 times higher). Lesser, but still significant, differences were found in the case of einfach (about 3 times higher frequency in the Berlin project), schon (more than twice as often in the Berlin corpus) and eben, after all representing 7,9\% of the particles in the Berlin corpus. A considerable difference was further found with ruhig and with the particle combination nun mal. However they only occurred 3 resp. 4 times in total $(0.1 \mathrm{resp} .0 .5 \%$ of the respective particle occurrences) in the case of nun mal and once resp. twice in the case of ruhig, being thus far too infrequent as to draw any conclusions from the differences.

How then can we explain these differences? In the case of denn it seems reasonable to assume that in the comparative corpus more questions were asked. In contrast to the Berlin corpus, where the verbal expressions of the interviewer were deliberately not considered, in the comparative case all utterances were equally included. ${ }^{9}$ In order to even out this different treatment of the underlying material, the occurrences of denn will not be considered further in either corpora. The results then are as follows:

\footnotetext{
9 This was already necessary in so far as the transcriptions in many cases were based on conversations with more than one person, also including the case of multiple interviewers (a school class interviewed a film producer).
} 
Berlin corpus without denn, mal, wohl:

\begin{tabular}{|c|c|c|}
\hline Particle & absolute & $\%$ \\
\hline auch & 1887 & $45.2 \%$ \\
\hline halt & 611 & $14.6 \%$ \\
\hline ja & 515 & $12.3 \%$ \\
\hline einfach & 401 & $9.6 \%$ \\
\hline eben & 333 & $8.0 \%$ \\
\hline eigentlich & 199 & $4.8 \%$ \\
\hline schon & 182 & $4.4 \%$ \\
\hline doch & 47 & $1.2 \%$ \\
\hline nun mal & 3 & $0.1 \%$ \\
\hline ruhig & 1 & $0.0 \%$ \\
\hline Total & 4179 & $100.0 \%$ \\
\hline
\end{tabular}

Table 5: Particle ranking without denn, mal, wohl; Berlin corpus
Comparative corpus without denn, mal, wohl:

\begin{tabular}{|c|c|c|}
\hline Particle & absolute & $\%$ \\
\hline auch & 340 & $41.2 \%$ \\
\hline ja & 177 & $21.5 \%$ \\
\hline doch & 152 & $18.4 \%$ \\
\hline eigentlich & 61 & $7.4 \%$ \\
\hline eben & 38 & $4.6 \%$ \\
\hline einfach & 28 & $3.4 \%$ \\
\hline schon & 16 & $1.9 \%$ \\
\hline halt & 7 & $0.8 \%$ \\
\hline nun mal & 4 & $0.5 \%$ \\
\hline ruhig & 2 & $0.2 \%$ \\
\hline Total & 825 & $100.00 \%$ \\
\hline
\end{tabular}

Table 6: Particle ranking without denn, mal, wohl; comparative corpus

Relations:

\begin{tabular}{|c|c|c|}
\hline Partikel & $\mathrm{B} \Rightarrow \mathrm{C}$ & $\mathrm{B} \Leftarrow \mathrm{C}$ \\
\hline auch & 1.1 & 0.9 \\
\hline doch & 0.1 & $\mathbf{1 6 . 4}$ \\
\hline eben & 1.7 & 0.6 \\
\hline eigentlich & 0.6 & 1.6 \\
\hline einfach & 2.8 & 0.4 \\
\hline halt & $\mathbf{1 7 . 2}$ & 0.1 \\
\hline ja & 0.6 & 1.7 \\
\hline ruhig & 0.1 & 10.1 \\
\hline schon & 2.2 & 0.4 \\
\hline nun mal & 0.1 & 6.8 \\
\hline
\end{tabular}

Table 7: Frequency comparison between Berlin and comparative corpus

( $\mathrm{B}=$ Berlin corpus, $\mathrm{C}=$ comparative corpus; the arrow shows the direction of the relation)

The difference in some cases - especially doch and halt - is again extraordinarily high. The fact that it is the comparative corpus, and not the Berlin corpus, which corresponds to the average results, becomes clear when comparing the results of the analysis with those of the study in 1986:10

\footnotetext{
10 Since the particle auch has not been assessed with the same criteria in the different studies it will not be considered in this comparison either. Further, only those particles will be considered that occur in both corpora. Thus, some particles that only rarely occur and under certain conditions - such as the particle aber as expression of astonishment or surprise - will also be excluded.
} 
Frequency order of rank according to Hentschel (1986), reduced sample:

\begin{tabular}{|c|c|c|}
\hline Particle & absolute & $\%$ \\
\hline$j a$ & 123 & $41.4 \%$ \\
\hline doch & 84 & $28.3 \%$ \\
\hline eben & 41 & $13.8 \%$ \\
\hline schon & 15 & $5.1 \%$ \\
\hline eigentlich & 12 & $4.0 \%$ \\
\hline einfach & 12 & $4.0 \%$ \\
\hline halt & 9 & $3.0 \%$ \\
\hline ruhig & 1 & $0.3 \%$ \\
\hline Total & 297 & $100.0 \%$ \\
\hline
\end{tabular}

Table 8: Particle ranking without denn, mal, wohl; data from Hentschel (1986)
Frequency order of rank, reduced comparative corpus:

\begin{tabular}{|c|c|c|}
\hline Particle & absolute & $\%$ \\
\hline$j a$ & 177 & $36.8 \%$ \\
\hline doch & 152 & $31.6 \%$ \\
\hline eigentlich & 61 & $12.7 \%$ \\
\hline eben & 38 & $7.9 \%$ \\
\hline einfach & 28 & $5.8 \%$ \\
\hline schon & 16 & $3.3 \%$ \\
\hline halt & 7 & $1.5 \%$ \\
\hline ruhig & 2 & $0.4 \%$ \\
\hline Total & 481 & $100.00 \%$ \\
\hline
\end{tabular}

Table 9: Particle ranking without denn, mal, wohl; comparative corpus

Relations:

\begin{tabular}{|c|c|c|}
\hline Particle & $\mathrm{H} \Rightarrow \mathrm{C}$ & $\mathrm{H} \Leftarrow \mathrm{C}$ \\
\hline ja & 1.1 & 0.9 \\
\hline doch & 0.9 & 1.1 \\
\hline eben & 1.7 & 0.6 \\
\hline schon & 1.5 & 0.7 \\
\hline eigentlich & 0.3 & 3.1 \\
\hline einfach & 0.7 & 1.4 \\
\hline halt & 2.1 & 0.5 \\
\hline ruhig & 0.8 & 1.2 \\
\hline
\end{tabular}

Table 10: Frequency comparison between Hentschel (1986) and comparative corpus $(\mathrm{H}=\mathrm{Hentschel}, \mathrm{C}=$ comparative corpus; the arrow shows the direction of the relation)

The similarity of the particle distribution between these two corpora is evident. The only real deviation is found with eigentlich occurring three times more frequently in the comparative corpus. In light of the absolute numbers, however, this deviation is not really significant. The similarity of the frequency distribution is even more surprising if one considers that the transcribed text is based on different types of conversation: while the corpus from Hentschel (1986) comprises of various kinds of conversation with differing degree of privacy, only public and semi-public dialogues of an interview character were chosen for the comparative corpus. 
No matter how one evaluates the deviations between these two corpora in detail, one thing is certain: $j a$ and doch are - in exactly this order - the most frequent modal particles in German, and among the particles marking 'unalterability' (eben, halt, nun mal), the more neutral eben always occurs more frequently than the slightly emotional halt (for further details between regional frequency differences between eben and halt see the following). This is not the case in the Berlin corpus: here, halt ranks highest occurring more than 17 times more frequently than in the comparative corpus; $j a$ is only ranked in the third place. The difference is almost the same with doch occurring 16 times less frequently than in the comparative corpus. Here, one can no longer assume natural frequency variation as one would expect for this kind of data.

\section{$5 \quad$ No contradiction anticipated}

For these reason the semantics of the relevant particles becomes all the more important. Only their meaning as well as the communicative function that these spontaneously and without conscious planning used elements have can explain these enormous differences in frequency.

Let us first consider doch. What is it that makes this particle the second most frequently used in average discourses, and yet leads to a more than 15 times lesser frequent use with the mothers interviewed? Doch in all its variations of occurrence, i.e. also in emphasized types of occurrence as conjunction (Ich wäre gern gekommen, doch ich hatte keine Zeit 'I would have liked to come, but I didn't have the time'), as adverb (Und sie bewegt sich doch! 'and it does move!' - emphasized doch) or as response particle (Kommst du nicht mit? - Doch! 'Aren't you coming? - Yes!'), always implies a contradiction. This contradiction becomes evident in these emphasized variants. In case of the unemphasized modal particle doch, however, the contradiction is, in a way, also not emphasized - but unmistakably present in the background - and yet still exists. In requests such as Setzen Sie sich doch! ('Do sit down!'), doch implies that the person addressed remained-standing in spite of the possibility of sitting down and despite the wish or expectation of the person speaking. Since, at the same time, the entire situational context including the person's action is included, the particle makes the request sound more polite than a mere Setzen Sie sich! ('Sit down!'). In assertion sentences the included contradiction can often not be identified directly at all: sentences like Du weißt doch ('you know') or Wir waren doch neulich in diesem Film... ('We went to this movie recently....') may obviously imply something like 'although you might not recall this at the moment'. In contrast, the contradiction becomes evident in utterances like Das kannst du doch nicht machen! ('You can't do this!') (for more detail, see Hentschel 2003; Pasch et al. 2003; König/Stark/Requard 1990; Weydt/Hentschel 1983).

In the sample of the mothers interviewed, there seems to have been less contradiction in general, both in the implicit and explicit, imagined and real context. In total, there were only 50 occurrences of doch, of which three had only been used as quotation. ${ }^{11}$ Thus the Berlin corpus did not even contain one third of the doch occurrences in comparison to the comparative corpus, which was less than half as large. It is also significant that the usage of doch in some cases neither refers to the questions by the interviewer nor to the interpretation of the picture cards (cf. e.g.: Die Couch, die kenn ich doch schon. 'The couch, I know it already'; Ach, da ist doch wieder die Tigerentenmutter, die kenn ich doch schon. 'O, there is the tigerduck-mother again, I know her already'; Interview 33). In these cases, the mothers referred either to a behaviour shown on the picture that was tentatively judged somewhat negatively by the mother (cf. finde ich dann noch ansprechender als, ehm, das Bild daneben,

11 (A fictive mother says so her child:) "Guck mal, hier klappert es doch" ('look, it's rattling'); "Komm, wir lernen doch laufen" ('come on, we are learning to walk'; Interview 14); "Zeig doch mal, wie das schon geht" ('show me how you can already do this'; Interview 33): 
wo die Mutter doch einigermaßen entfernt oder doch so'n bisschen, ehm, ja, distanzierter zum Kind ist; appr. 'I find it a little more appealing than, uhm, the picture next to it where the mother is to some extent farther away or somewhat, uhm, yes, distanced to the child' [Interview 40]; erst mal soll's doch sich lernen umzudrehen auf die Seite und krabbeln und so weiter; 'First, he should learn to turn to the side and to crawl and so on' [Interview 14]), or a comparison with the own situation that obviously was not expected (cf. Hmm, das haben wir auch schon gemacht. Hier so auf den Fuß legen, ne, das ist doch, ja, genau. 'Hmm, we have done this already, too. Here this laying on the foot, you know, that is, yes, exactly' [Interview 27]).

All in all one can conclude that in the world view of the mothers interviewed there is little or no contradiction at all (in as much as 15 of the 40 interviews analyzed there was no doch in modal function) in what they uttered. This is an unusual position. It must mean that the mothers interviewed were very sure about what they said and also that they assumed that the entire environment, including the interviewer, shared their opinion.

\section{Unalterability, seen positively}

In contrast, the particles halt and eben serve a completely different function. They convey that what is being said is unalterable and beyond one's influence, so that their meaning is usually described with terms like 'irreversibility' or 'unalterability' (Unabänderlichkeit; cf. e.g. Authenrieth 2002: 89 as well as the references given there). ${ }^{12}$

Most authors agree that there is a distinct regional difference between eben and halt. Although speakers of all dialects use eben, halt is considered to be restricted to the Southern part of the language area (cf. Hentschel 1986: 174-178 for more detail): The local distribution is most clearly reflected by a map that can be found in Eichhoff (1979: 103)

12 For the semantics of eben and halt, see also Weydt/Hentschel (1983: 9f, 12f), Métrich/Faucher/Courdier (1995) or the entries in the dictionaries Wahring (2005: s.v. eben/halt), Deutsches Universalwörterbuch (2001: s.v. eben/halt), Grimm/Grimm (1854/1984-99, s. v. eben/halt): Thurmair (1989: 120) additionally presumes an underlying semantic feature 'evidence' as central to the meaning in the case of the particle eben (cf. also Molnár 2002: 34). 


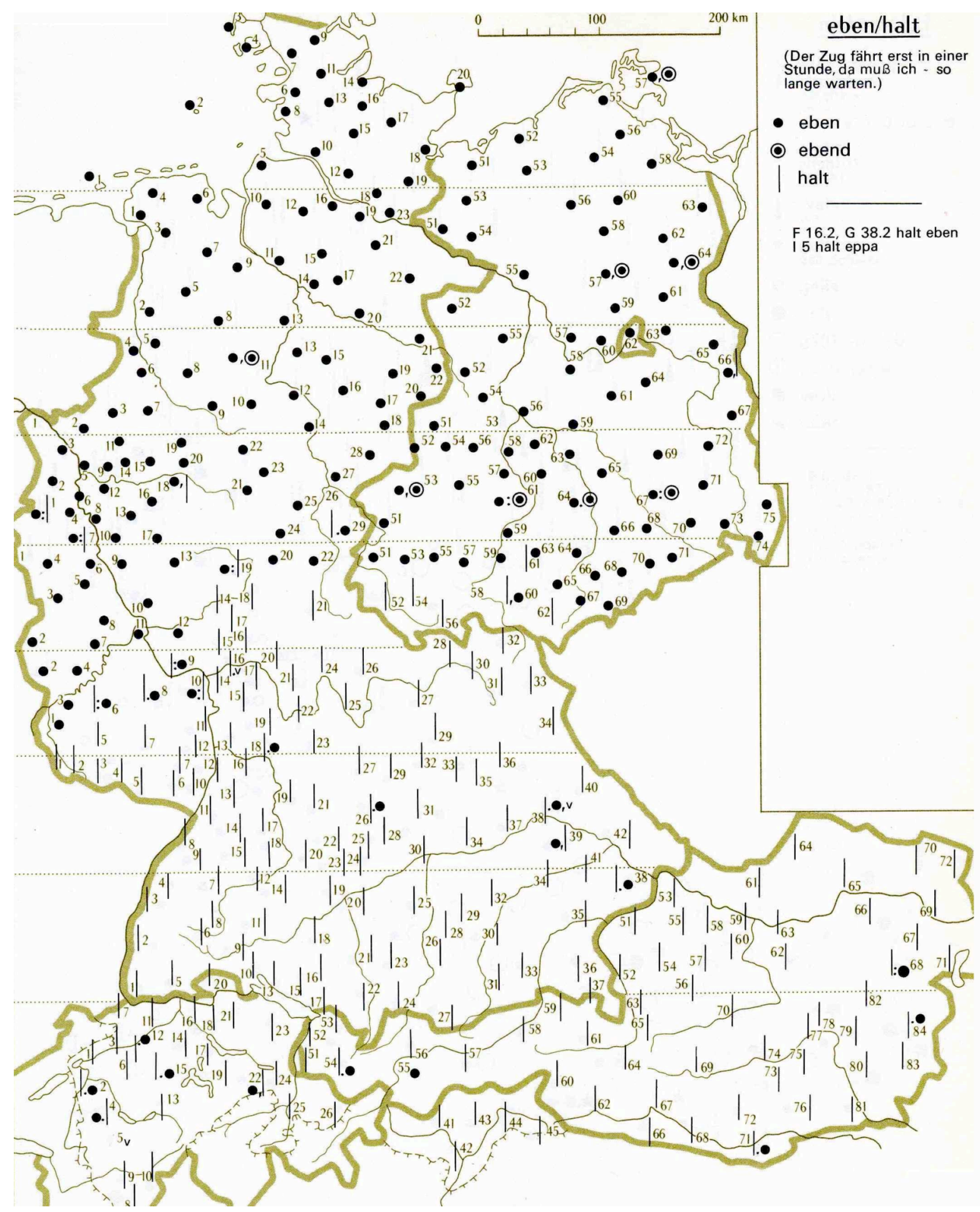

Figure 1 (taken from Eichhoff 1979: 103)

This regional difference started to balance out some time ago (cf. Hentschel 1986: 177f.; Retti 2005, s.v. halt), but is still considered to be valid. This is reflected by the respective entries in contemporary monolingual dictionaries, where halt is described as "Southern German" (Wahrig 2005, s.v. halt) or "especially Southern German, Austrian, Swiss" (Duden 2001, s.v. halt; cf. also Retti 2005). It is therefore most remarkable that the Berlin corpus shows a significantly higher frequency of halt than the texts of the 1986 corpus and of the comparative corpus, which came largely from the southern part of Germany. In particular, the Berlin corpus contains 21 speakers who are Berliners, and 13 more from other German cities 
belonging to the "eben area" as shown in the map in figure 1, while the remaining six mothers are either of Southern provenience (Ulm, Würzburg, Saarland; three mothers) or their regional origins are unknown (three cases). The 34 speakers from the "eben area", $85 \%$ of the interviewees, use 462 of the 609 halt that the corpus contains (75\%). In other words: as far as the frequency of their halt usage is concerned, there is only a slight difference between the Northern and Southern speakers, and the huge regional differences that the map in figure 1 suggests cannot be remotely verified. In the case of eben, on the other hand, the $85 \%$ of Northerners in the sample prove to be the source of $94 \%$ of all eben (311 of 353). It seems, therefore, that these speakers have simply added halt to their vocabulary, without any consequences for their use of eben, which they use slightly more often than the Southern mothers. ${ }^{13}$ The southerners, in turn, also make use of both particles, with a slight preference for halt. These findings emphasize the relevance of the strong deviation from the normal ranking order in halt and eben that can be observed in the Berlin corpus in comparison to others, and make this deviation highly significant.

In order to interpret these findings, it is necessary to consider the connotative differences between the two particles. Grimm's dictionary (Grimm/Grimm 1862-1984/1999: s.v. halt) already states that, other than eben, halt conveys a 'homely coloration' ("trauliche färbung") to the utterance. In a study in the 1980s, the semantic differential technique was used in order to detect the speakers' attitude towards the particles. The test persons were asked to evaluate minimal pairs of utterances, which differed only in the particle used. The following diagrams show some examples for positive resp. negative connotations (in percentages).

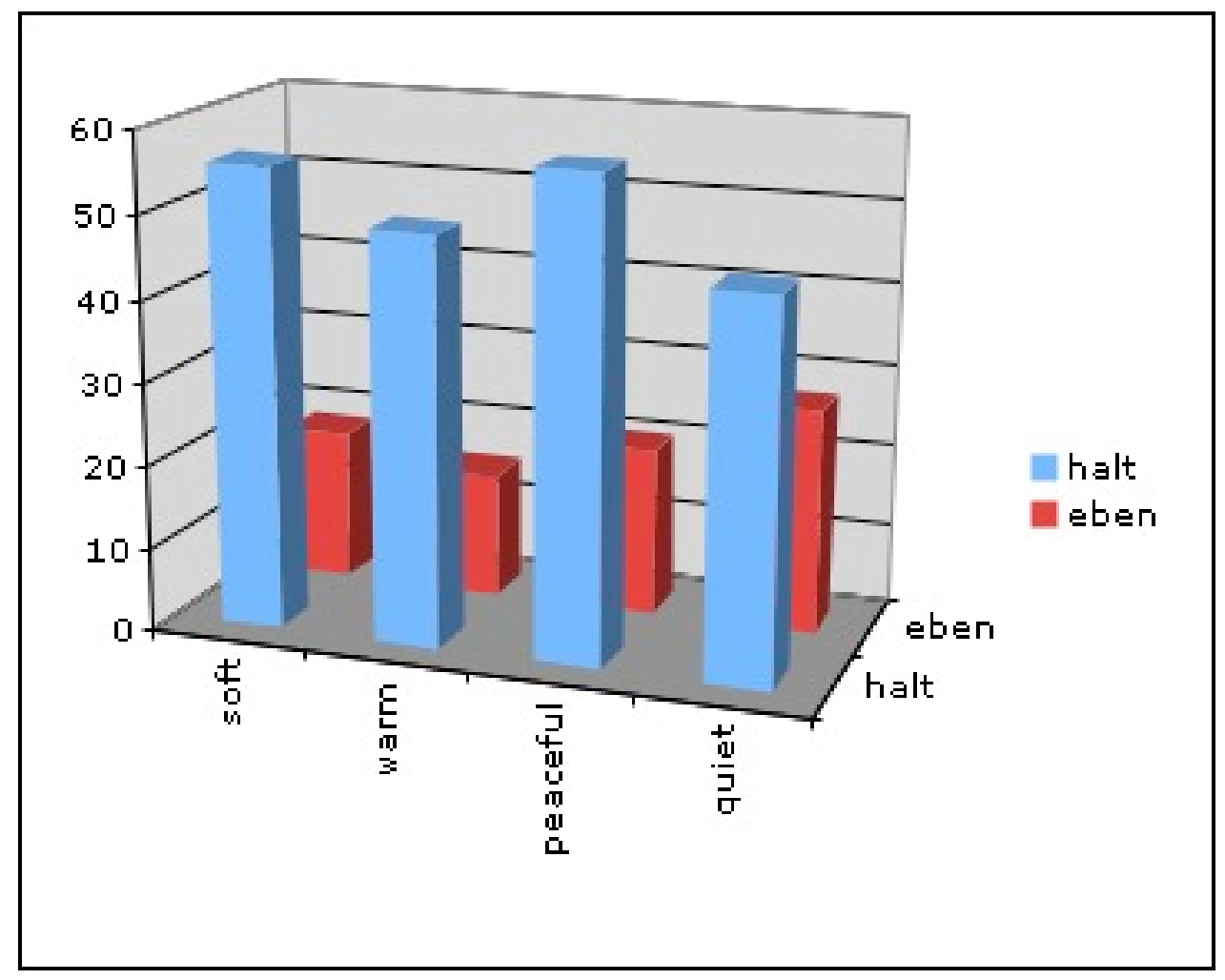

\footnotetext{
13 Since there are only six non-Northern mothers and only three of them could be clearly identified as belonging to the "halt area", these numbers have, of course, to be taken with a grain of salt. If one considers the three Southern mothers alone, it turns out that they, making up only 7,5\% of the sample, used $16 \%$ of all the halt in the corpus, but only $0.6 \%$ of the eben. Whatever conclusions one might wish to draw from these few cases, it remains clear that the "eben area" speakers have added halt to their vocabulary, using it with uncommon frequency in the interviews discussed here.
} 
Figure 2: Positive connotations of utterances with halt vs. eben (after Hentschel 1986: 182)

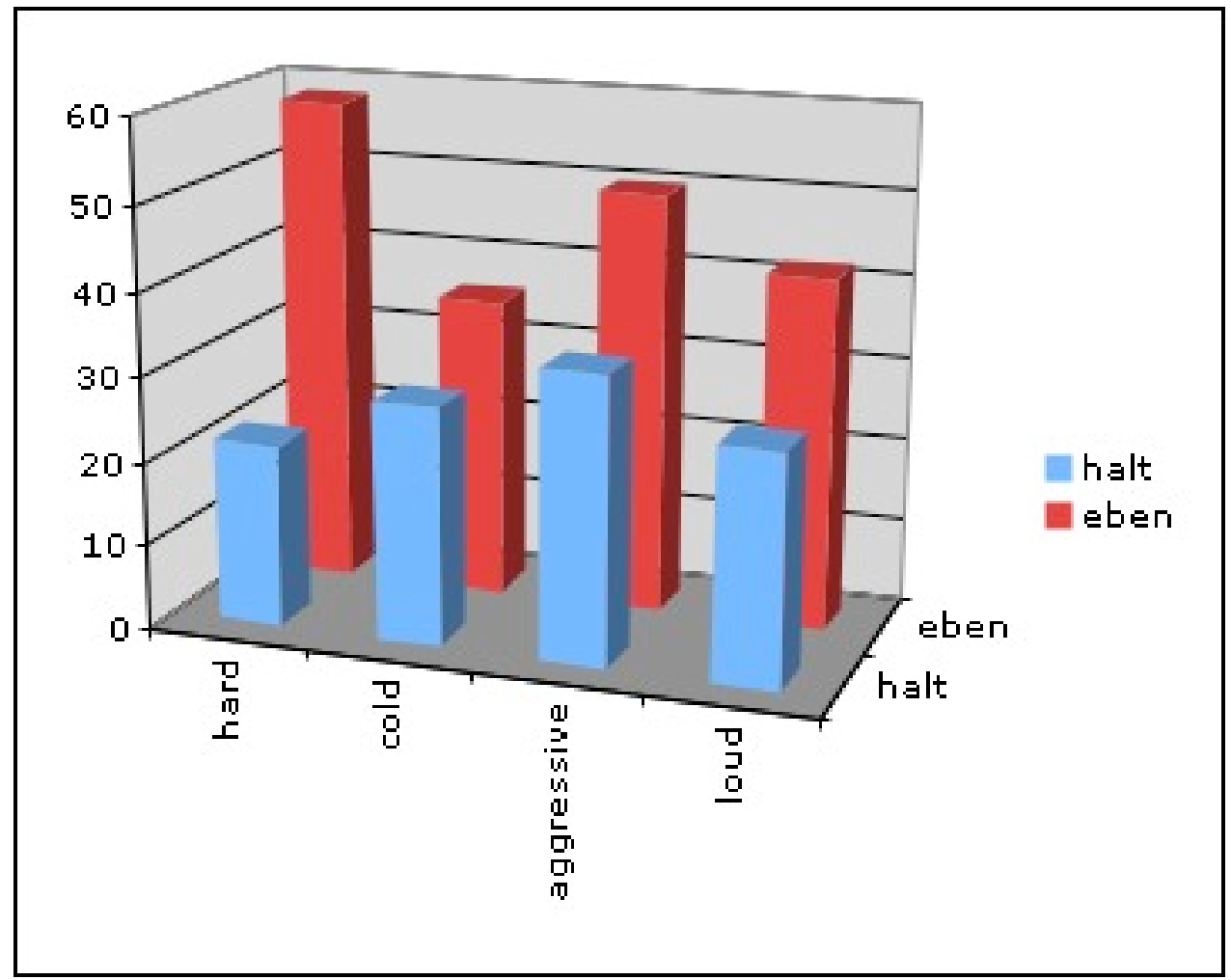

Figure 3: Negative connotations of utterances with halt vs. eben (after Hentschel 1986: 182)

Obviously, connotations like these were the reason behind the astonishingly high frequency of halt in the interviews. The mother felt not only sure that the concepts they were speaking about were unalterable; they also had positive feelings towards them.

The sense of a positively perceived unalterabilty was the underlying attitude expressed in the particle use of all the mothers throughout all the interviews. It is therefore interesting to see if there are also underlying parental concepts throughout the interviews that would statistically correspond with these linguistic findings.

\section{$7 \quad$ The unanimity of parental concepts}

The unanimity of parental concepts expressed by the Berlin mothers supports the view of the cultural fixed, ready-made nature of parental beliefs. This contradicts the assumption that Western middle class mothers are usually regarded as highly insecure with respect to parenting practices with their young infants. This insecurity is based on the fact that their first child is usually at the same time the first baby with whom mothers are in touch. The economic success of parent guidebooks and magazines is understood as expression of this insecurity. Furthermore high amounts of crying and sleeping problems as reported by pediatricians and family counselors are regarded as reflecting deep insecurity, and trial and error parenting practices. Since our sample mainly comprises of first time mothers, this insecurity could have been expected (cf. Keller/Völker/Yovsi 2005).

What, then, are the concepts they nevertheless so clearly believe to be indisputable? A content analysis of these same interviews has revealed that the Berlin mothers value especially the concept of Beschäftigung (appr.: 'occupation', 'engagement'). Beschäftigung it is semantically not equivalent to playing. It covers playing and stimulating, thus focusing on the child, but it also denotes engagement and involvement on the part of the carer. 
Beschäftigung is the omnibus concept of German mothers. It covers talking to the child and telling the child stories, facial interaction and eye contact, playing, body contact and presenting a toy. The developmental relevance of Beschäftigung is equally varied. It helps in achieving developmental milestones like language acquisition, developing the senses and learning in general. It helps supporting brain maturation and cognitive development; it also establishes contact, builds trust, and leads to relationship and love. As a consequence babies feel attended to (beachtet) and realize that they have a person who relates to them (Bezugsperson).

\section{Example:}

"Yes that is [halt] also with that, here the mother is playing with the baby and explaining something to him, probably about the toy, and [halt] engaging herself, because children [halt nun mal] want to be engaged, and they need it, too, for their development." ("Ja das ist halt auch mit dem, die Mutter hier mit dem Baby spielt und ihm was erklärt sicherlich zu dem Spielzeug und sich halt beschäftigt, weil Kinder wollen halt nun mal beschäftigt werden und die brauchen das auch für die Entwicklung..."; Mother B 21; translation by the authors). ${ }^{14}$

Thus, the concept itself is open to individual definition by individual mothers stressing different aspects of Beschäftigung. Nevertheless they feel that there is unanimous cultural understanding of their particular view on early childcare.

\section{Conclusion}

The linguistic analysis confirms the assumption of cultural models of childcare, that are shared within cultural environments like our middle class, highly educated urban German mothers from the capital city, Berlin. At the same time, this confirms the existence of implicit knowledge about childcare. It can be assumed that this parenting program is based on a universal inborn repertoire (e.g. Papou\%oek/Papou\%oek 1987), which is then shaped by the cultural environment during ontogenetic developmental pathways. This assumption is also supported by reports from parents of crying or non sleeping babies, who report an intuitive tendency to give particular forms of care but think that these may be wrong due to conscious reasoning about the developmental consequences (Keller/Lohaus et al. 2004).

The very unusual particle use pattern the mothers display, with their abundance of halt and eben and the remarkable absence of doch, show clearly that the propositions uttered are believed to be part of an undisputable, general truth. This is all the more convincing as particles are not consciously applied and allow therefore an insight in underlying thought structures.

Thus, our results can be interpreted as supporting the existence of a solid and intuitive, although only partly consciously accessible knowledge base of early parenting practices, although it may be disconnected from the behavioural parenting repertoire. Thus, these results may even carry important implications for family counselling. Further studies are needed that analyze the different levels of the nature of cultural concepts of parenting in cultural environments that do not value uniqueness and individual expressions like the independent families from Berlin middle class society.

\section{References}

Autenrieth, Tanja (2002): Heterosemie und Grammatikalisierung bei Modalpartikeln. Tübingen.

\footnotetext{
${ }^{14}$ For more examples, see appendix.
} 
Blühdorn, Hardarik/Schmidt-Radefeldt, Jürgen (eds.) (2003): Die kleineren Wortarten im Sprachvergleich Deutsch-Portugiesisch. Frankfurt a. M. (= Rostocker romanistische Arbeiten 7).

Catalani, Luigi (2004): Deutsch, Französisch und Spanisch im Kontrast mit dem Italienischen. Vier Beiträge zum Sprachvergleich. Frankfurt a. M. etc.

D'Andrade, Roy (1984): "Some propositions about the relations between culture and human cognition". In: Stigler, James W./ Shweder, Richard A./Herdt, Gilbert (eds.): Cultural psychology. Essays on comparative human development. 65-129. New York.

Dudenredaktion (eds.) (2001): Deutsches Universalwörterbuch. Mannheim etc.

Eichhoff, Jürgen (1979): Wortatlas der deutschen Umgangssprachen. Bd. 2. Bern etc.

Goodnow, Jacqueline J. (1985): "Change and variation in ideas about childhood and parenting". In: Sigel, Irving E. (ed.): Parental belief systems. Hillsdale, NJ, Erlbaum: 235270.

Grimm, Jacob/Grimm, Wilhelm (1854/1984-99): Deutsches Wörterbuch. Fotom. Nachdruck der Erstausg. München.

Harwood, Robin L. (1992): "The influence of culturally derived values on Anglo and Puerto Rican mothers' perceptions of attachment behaviour". Child Development 63: 822-839.

Hentschel, Elke (1980): "Abtönungspartikeln als stilistische Merkmale des Alltagsgesprächs." In: Kühlwein, Wolfgang/Rasch, Albert (eds.)(1980): Sprache und Verstehen. Bd. 2, Tübingen: 142-145.

Hentschel, Elke (1986): Funktion und Geschichte deutscher Partikeln. Ja, doch, halt und eben. Tübingen. (= Reihe Germanistische Linguistik 63).

Hentschel, Elke (1991): "Aspect versus particle: Contrasting German and Serbo-Croatian". Multilingua 10-1/2: 139-149.

Hentschel, Elke (2001): "Pragmatische Markierungen im Sprachvergleich". In: Ferrer, Hang/Pons, Salvador (eds.): La pragmática de los conectores y las partículas modales. València: 115-126. (= Quaderns de filologia: estudis lingüístics 6).

Hentschel, Elke (2003): "Wenn Partikeln frech werden". In: Held, Gudrun (ed.): Partikeln und Höflichkeit. Frankfurt a. M.: 55-72.

Hentschel, Elke/Weydt, Harald (2002): "Die Wortart 'Partikel'". In: Cruse, Alan D. et al. (eds.): Lexikologie. Lexicology. Ein internationales Handbuch zur Natur und Struktur von Wörtern und Wortschätzen. An international handbook on the nature and structure of words and vocabularies. Berlin/New York: 646-653.

Kasper, Gabriele (1997): Can pragmatic competence be taught? Honolulu: http://www.nflrc.hawaii.edu/NetWorks/NW06. (= NetWork 6).

Keller, Heidi (2002): "Culture and development: Developmental pathways to individualism and interrelatedness". In: Lonner, Walter J./Dinnel, Dale L./Hayes, Susan A./Sattler, Don N. (eds.): OnLine Readings in Psychology and Culture. Bellingham: http://www.wwu.edu/ culture.

Keller, Heidi (2003): Socialization for competence. Cultural models of infancy. Human Development 46.5: 288-311.

Keller, Heidi/Demuth, Carolin (2005): "Further Explorations of the 'Western Mind'. EuroAmerican and German Mothers' and Grandmothers' Ethnotheories". Forum Qualitative Sozialforschung/Forum: Qualitative Social Research 7(1), Art 5. http://www.qualitativeresearch.net/fqs-texte/1-06/06-1-5-e.htm [June 7, 2006].

Keller, Heidi/Demuth, Carolin/Yovsi, Relindis D. (2004): Independence and interdependence as socialization goals of Cameroonian women. Paper presented at the XXVIIIth International Congress of Psychology, Beijing, China, August 8-13.

Keller, Heidi/Hentschel, Elke et al. (2004): "The psycho-linguistic embodiment of parental ethnotheories. A new avenue to understand cultural differences in parenting". Culture/Psychology 10.3: 293-330. 
Keller, Heidi/Yovsi, Relindis D./Voelker, Susanne (2002): "The role of motor stimulation in parental ethnotheories. The case of Cameroonian Nso and German women". Journal of Cross-Cultural Psychology 33.4: 398-414.

Keller, Heidi/Völker, Susanne/Yovsi, Relindis D. (2005): "Conceptions of parenting in different cultural communities. The case of West African Nso and Northern German women". Social Development 14.1: 158-180.

König, Ekkehard/Stark, Detlef/ Requardt, Susanne (1990): Adverbien und Partikeln. Ein deutsch-englisches Wörterbuch. Heidelberg.

Lohaus, Arnold/Völker, Susanne/Keller, Heidi/Cappenberg, Martina/Chasiotis, Athanasios (1998): "Wahrgenommene kindliche Problemlage und mütterliche Interaktionsqualität: eine längsschnittliche Zusammenhangsanalyse" ['Perceived infant's problems and maternal interactional quality. A longitudinal analysis of relationships']. Zeitschrift für Entwicklungspsychologie und Pädagogische Psychologie 30, 3: 111-117.

LeVine, Robert A. (1988): "Human parental care: universal goals, cultural strategies, individual behaviour." In: LeVine, Robert A./Miller, Patrice M./West, Mary M. (eds.): Parental behaviour in diverse societies. San Francisco, CA, Jossey-Bass, Inc.: 3-12. (= New directions for child development 40).

Métrich, René/Faucher, Eugène/Courdier, Gilbert (1995): Les invariables difficiles: dictionnaire allemand-français des particules, connecteurs, interjections et autres 'mots de la communication' 2: Bald - geradezu. 4. éd., rev. et corr. Nancy (= Bibliotheque des nouveaux cahiers d'Allemand 2.2: Collection outils).

Miller, Peggy J. et al. (1997): "Personal storytelling as a medium of socialization in Chinese and American families". Child Development 68.3: 557-568.

Molnár, Anna (2002): Die Grammatikalisierung deutscher Modalpartikeln. Frankfurt a. M. etc. (= MetaLinguistica 12$)$.

Monteiro Resende, Sérvulo (1995): Die Wiedergabe der Abtönungspartikeln doch, ja, eben und halt im Englischen auf der Grundlage literarischer Übersetzungen. Dissertation, Universität Bonn.

Ochs, Elinor (1982): "Talking to children in Western Samoa." Language in Society 11: 77104.

Ormelius-Sandblom, Elisabeth (1997): Die Modalpartikeln ja, doch und schon. Zu ihrer Syntax, Semantik und Pragmatik. Stockholm. (= Lunder germanistische Forschungen 61).

Ortmann, Wolf Dieter (1975): Hochfrequente deutsche Wortformen I. München.

Papou\%oek, Hanu\%o/ Papou\%oek, Mechthild (1987): "Intuitive parenting: A dialectic counterpart to the infant's integrative competence". In: Osofsky, Joy Doniger (ed.): Handbook of infant development. Second ed. New York: 669-720.

Pasch, Renate et al. (2003): Handbuch der deutschen Konnektoren. Linguistische Grundlagen der Beschreibung und syntaktische Merkmale der deutschen Satzverknüpfer (Konjunktionen, Satzadverbien und Partikeln). Berlin.

Rabain-Jamin, Jacqueline/Sabeau-Jouannet, Emilie (1997): "Maternal speech to 4-month-old infants in two cultures: Wolof and French." International Journal of Behavioural Development 20.3: 425-451.

Rabanus, Stefan (1996): Die Sprache der Internet-Kommunikation. Mainz.

Ratner, Carl (2002): Cultural psychology. Theory and method. New York.

Retti, Gregor (2005): Datenbank zur deutschen Sprache in Österreich. http://oewb.retti.info/oewb/index.html.

Ruoff, Arno (1981): Häufigkeitswörterbuch gesprochener Sprache. Gesondert nach Wortarten, alphabetisch, rückläufig alphabetisch und nach Häufigkeit geordnet. Unter Mitarbeit von Harald Fuchs, Bernhard Gersbach, Rainer Graf und Simone Thiers. Tübingen. 
Shweder, Richard A. (1995): "The confession of a methodological individualist". Culture and Psychology 1.1: 115-122.

Sueiro Orallo, Irene (2002): Deutsche Modalpartikeln und ihre Äquivalenzen im Galicischen. Ein Beitrag zur kontrastiven Linguistik. Frankfurt a. M. etc. (= Bonner Romanistische Arbeiten 81).

Super, Charles M./Sara Harkness (1996): "The cultural structuring of child development". In: Berry, John W./Dasen, Pierre R./Saraswathi, T. S. (eds.): Basic processes and human development. Second edition 1997. Boston, Allyn/Baco: 1-39. (= Handbook of Crosscultural psychology 2).

Thurmair, Maria (1989): Modalpartikeln und ihre Kombinationen. Tübingen.

Wahrig, Gerhard (2005): Deutsches Wörterbuch. Hrg. von Renate Wahrig-Burfeind. Siebte, vollständig neu bearbeitete und aktualisierte Auflage Gütersloh.

Wang, Qi (2001): "Cultural effects on adults' earliest childhood recollection and self description: Implications for the relation between memory and the self". Journal of Personality and Social Psychology 81.2: 220-233.

Weisner, Thomas S./Gallimore, Ronald/Jordan, Cathie (1988): "Unpackaging cultural effects in classroom learning: Native Hawaiian peer assistance and child generated activity". Anthropology and Education Quarterly 19: 327-353.

Weydt, Harald/Hentschel, Elke (1983): "Kleines Abtönungswörterbuch." In: Weydt, Harald (Hg.): Partikeln und Interaktion. Tübingen: 3-24.

Weydt, Harald/Ehlers, Klaas-Hinrich (1987): Partikel-Bibliographie. Internationale Sprachenforschung zu Partikeln und Interjektionen. Frankfurt a. M. etc.

\section{Appendix: Examples from the interviews}

\section{Example 1:}

(...) und und, ehm, so die Zwiesprache, des, sage ich mal, was, ehm, eine ganz schöne Kombination zum Stillen einfach ist, um eben so dem Kind auch, eh, eben die Sicherheit zu geben, ne, dass man eben da ist. (...)

Ich versuche halt immer, irgendwie kindgerecht oder gerade so in der ersten Phase so das, was so wichtig ist, sehen, fühlen, hören, mit dem Kind zu machen. [Interview B1]

\section{Example 2}

Ich weiß nicht, also ich denke, vielleicht ist das auch völlig falsch, keine Ahnung, ich denke immer, wenn ich da bin und Zeit habe, dann kann ich auch ihn irgendwie bemuttern. Und wenn ich keine Zeit habe, dann bin ich auch froh, wenn er das alleine kann, also das kann er eben alleine, auch eine ganze Weile, ganz, ganz friedlich und fröhlich dabei. Und, und das sind denn eben die Sachen (...). [Interview B2]

\section{Example 3}

(...) wenn sie da so, aber das finden die halt immer schön. Oder überhaupt noch so, der Mama halt einfach zugetan. [Interview B3]

\section{Example 4}

Das ist eben wichtig, um die taktilen Sinne zu stärken, so überhaupt zu lernen. [Interview B5] 


\section{Example 5}

(...) das ist sicherlich auch noch wichtig - es braucht ja auch den Körperkontakt und die Reize halt, weil ja die Verbindungen zwischen den Gehirnzellen erst mal noch gebildet werden. [Interview B6]

\section{Example 6}

(...) spielen sie jetzt mit der Mutter. Dass das eben auch gefördert wird oder, ja, man kann das Kind halt nicht in der Ecke stehen lassen. [Interview B7]

\section{Example 7}

Also, das ist ehm sicher halt das Beste. (...) Das ist einfach, dass sich die Mutter mit dem Kind beschäftigt, würde ich sagen. (...) Dass also ne Mutter einmal ihr Kind auf dem Arm hält und dann eben das Kind auf den Rücken liegend, ehm, streichelt oder sich mit dem beschäftigt. [Interview B8]

\section{Example 8}

Da liegt das Kind zwischen den Knien der Mutter und, ja, und wird auch eben, die Mutter versucht, Kontakt aufzunehmen und beschäftigt sich halt so mit dem liegenden Kind noch. [Interview B9]

\section{Example 9}

Ja, ich find hier die Situation hier auf dem Bild halt. Da ist die Mutter sehr sehr zugewandt und sehr sehr eng bei sich. Da ist halt der Kontakt halt auch sehr sehr nah auf dem Bild. Ja, das ist halt gut für das Kind und für die Mutter. [Interview B10]

\section{Example 10}

Aber auf der anderen Seite ist halt auch dieses Spielen unheimlich wichtig. [Interview B11]

\section{Example 11}

(...) also so, das sind halt das erste, das, das, das Kind eben in seiner, in seiner Entwicklung so weit zu fördern, also dass es eben schon sich jetzt mit neuen Gegenständen beschäftigt, ehm, und, ja, das würde ich so als dann als nächst wichtiges sagen. [Interview B12]

\section{Example 12}

Ja, da ist wieder das das wichtigste, weil ich es halt am wichtigsten finde halt auf das Kind einzugehen. [Interview B13]

\section{Example 13}

Das finde ich auch sehr, dieses Ansprechen des Kindes. Mhm, ja auch der Blickkontakt und, ehm, halt überhaupt Kommunikation (...). [Interview B14]

\section{Example 14}

Ist halt, jetz, im Alter von drei Monaten (...), fängt er an zu greifen auch ganz bewusst eben nach Dingen zu greifen. Das wird eben da mit der Quietscheente gefördert, ja. Man hält dem 
Kind etwas hin, was interessant aussieht, was es eben dann nicht nur mit den Augen aufnimmt, sondern durch das Tasten auch versteht. [Interview B15]

\section{Example 15}

(...) das hier oben ist ein bisschen mehr Motorik, also körperliches, körperliche Geschichten, da ist, (na d) ist auch wichtig, aber natürlich nicht so wichtig, wie halt, ehm, sich mit den Kindern beschäftigen und mit denen reden. [Interview B16]

\section{Example 16}

Also das ist dann ja auch wichtig, weil eben diese, ehm, Phasen, wo er wach wird, eh, wach ist jetzt denn schon sehr viel länger sind, als am Anfang, ne. Dann biete ich ihm halt so was. [Interview B17]

\section{Example 17}

Ehm, na ja, dass es halt angeregt wird, motiviert wird, ehm, mehr zu tun, mehr sich anzustrengen, was zu lernen. Mhm. [Interview B18]

\section{Example 18}

(...) und die Mama bespielt es halt so ein bisschen, und macht einfach mit ihm was, und guckt's an (...). [Interview B19]

\section{Example 19}

(...) ehm, und am Spiel finde ich eben auch wichtig, er lernt ja jetzt daran schon das Greifen durch so, ehm, durch so Spielzeug und so Stoff- äh, -puppen oder, (...) Und, ehm, nee, und damit er eben seine, eh, damit er eben übt, greifen übt und so, also was einfach für seine körperliche Entwicklung wichtig ist. [Interview B20]

\section{Example 20}

Ja das ist halt auch mit dem, die Mutter hier mit dem Baby spielt und ihm was erklärt sicherlich zu dem Spielzeug und sich halt beschäftigt, weil Kinder wollen halt nun mal beschäftigt werden und die brauchen das auch für die Entwicklung. [Interview B21; translation given in main text]

\section{Example 21}

(...) also das eine eben, weil man das Gefühl hat, ja, die, die verstehen sich gut, die reden miteinander irgendwie da, ja, sie beschäftigen sich schön miteinander irgendwie (...). [Interview B22]

\section{Example 22}

(...) und dann, und einerseits find ich dann eben gerade dieses Stillbild besonders schön, weilem- ich denke, dass Stillen halt sehr, sehr gut für Kinder ist, und auch halt eine positive em Mutter-Kind-Beziehung fördert. [Interview B23] 


\section{Example 23}

(...) hm, das find ich auch gut, weil die Mutti halt wieder das Kind liegt wieder auf'm Boden das ist, ja das hab ich ja schon gesagt das find ich halt immer sehr gut, wenn die Kinder auf'm Holzfussboden nur mit'ner Decke liegen, weil sich da halt die Muskulatur recht gut ausprägen kann. Weil die sich halt durch den Druck, durch den eigenen Körperdruck abstützen müssen und sich also alles gleichmäßig entwickelt. Die Mutti sitzt davor, die Mutti spielt mit dem Kind zusammen. [Interview B24]

\section{Example 24}

(..) ähm, und das ist eben der ganze Körper, der mit den Sinnen aufnimmt. [Interview B25]

\section{Example 25}

Ehm, das Spielen ist natürlich, eh, auch das wichtigste, weil durch das Spielen, eh, eben ganz viel gelernt wird. [Interview B26]

\section{Example 26}

Das macht Spass, da kullert es im Bauch, da ist Nähe, da ist halt für das Kind, ne und trotzdem Geborgenheit. [Interview B27]

\section{Example 27}

Und dann halt auch eventuell irgendwelche anderen Übungen machen, um, dass das Kind das halt wieder lernt oder besser lernt. [Interview B28]

\section{Example 28}

Und mal ist es halt eher son, son, son, zarteres mit ihm sprechen oder lächeln oder so. [Interview B29]

\section{Example 29}

Ja, es ist halt schön, zu Stillen einfach, ne. (...) Ja, das sieht mir auch danach aus, als würden die sich grad mit einander beschäftigen und so (...) Das macht man einfach gerne. [Interview B30]

\section{Example 30}

(...) wie die Mutter dem Kind halt ermöglicht seinen Körper kennenzulernen. [Interview B31]

\section{Example 31}

Also wahrscheinlich wird die Frau ihr Kind erst streicheln, dann wird sie halt mit den Füßchen spielen, und das ist halt schon so am, hier (wird) das Kind so schon am meisten gefördert, ehm. [Interview B32]

\section{Example 32}

Ich beschäftige mich gerne mit meinem Kind in spielerischer Form. (...) Auch eigentlich die Sinne fördern, aber eben auch die Liebe mit dabei. [Interview B33] 


\section{Example 33}

(...) aber genauso wichtig, halt ein Kind, wenn es Bewegungsdrang hat, das zu unterstützen, was die Bewegung fördert, und genauso wichtig ist halt auch, dass man ein Kind einfach mal weglegen kann und dann mit ihm einfach auch sein, oder neben dem Kind sitzt und mit dem Kind spielt, also, und genauso wichtig ist es, dass man einem Kind ab und zu mal Spielzeug gibt, weil es halt alles Aspekte sind, die ein Kind braucht. [Interview B34]

\section{Example 34}

(...) also Spielen halt mit Händen und Füssen, das finde ich, eh, auch wichtig, so für die Entwicklung. [Interview B35]

\section{Example 35}

Und die Mutter ist halt komplett nur mit dem Baby beschäftigt, mit nichts anderem, und das Baby ist komplett mit der Mutter beschäftigt. [Interview B36]

\section{Example 36}

(...) dass die beide so völlig auf einer Welle sind und so völlig Spaß miteinander haben. Na, das ist für das Kind halt wichtig. [Interview B37]

\section{Example 37}

(...) das Kind versucht schon ranzutatschen oder versucht schon zuzugreifen und, denke, die Mutter dies dann auch so positiv verstärkt und da da eben auch so eine Rückkopplung gibt, dass da auch so eine Kommunikation dann da passiert oder, in dem Moment. [Interview B38]

\section{Example 38}

(...) das Kind kriegt halt verschiedene Anregungen, mit denen es sich beschäftigen kann, und ich denke, die Mama holt dann halt ran, was, was es haben möchte, oder bietet ihm einfach verschiedene Sachen an, und man kann halt gucken, ehm, was interessiert das Kind und was interessiert es nicht, was es nicht interessiert, kann man beiseite tun oder halt zwei Wochen später noch einmal ausprobieren. [Interview B39]

\section{Example 39}

(...) und, ehm, Zärtlichkeit ist eben auch wichtig für, für die Entwicklung, für, auch für das Selbstbewusstsein des Kindes, was es entwickeln sollte (...). [Interview B40]

\section{Example 41}

$\mathrm{Hm}$, das ist ja beides so, ja, (also das halt) so erzählen mit dem Kind, vielleicht das hier, so beschäftigen mit dem Kind, ja. (...) ehm, und, und dazu ist es halt wichtig, dass es, ehm Kontakt von außen bekommt, also nicht nur immer so da liegt und sich alles anguckt. [Interview B41] 